\title{
The Influence of School-Based Curriculum on the Learning Process and Students' Achievement
}

\author{
Bambang Budi Wiyono \\ Department of Educational Administration \\ State University of Malang, Indonesia \\ bambang.budi.fip@um.ac.id
}

\begin{abstract}
School-Based Curriculum has been developed and implemented by schools in order to improve the education quality in Indonesia. The study was aimed at describing influence of the curriculum implementation on students' learning process and outcome. The study was conducted in East Java, with samples of 185 schools, 185 principals, and 570 teachers in four regencies taken by area cluster random sampling. The data collected by using questionnaire, interview, and documentation, and analysed by using descriptive statistics, Pearson Product Moment Correlation, and qualitative data analysis. The results showed that most schools at basic level of education have developed and implemented School-Based Curriculum. The arrangement process of the curriculum was referred to the right principles, but less involved all personnel optimally. The curriculum was also implemented with multimodel, multi-method, and multi-resource of learning, and furnished with local content and self-development subjects. There was some positive correlations among the quality of arrangement process, the ability of school resources, the internal and external supports for school, the success of curriculum implementation, and students' achievement with varied coefficients. The ability of human resources, the local content and self-development subjects had dominant impact on the students' achievement.
\end{abstract}

Keywords: school-based curriculum, teaching quality, learning process, student achievement, school achievement

\section{INTRODUCTION}

The improvement of quality of education was the main factor that determines the success of the development of the nation. The history of economic development in many industrialized countries proved that human investment has the most important role in the development process. Success of the development can only be achieved, when it was supported by qualified human resource. Based on the thesis statement, then, emerged a new development strategy which rests on the development of human resources through education, known by the term of human resources based economic development. That strategy that makes many countries like Singapore, Taiwan, and South Korea run into a newly industrialized country. Therefore, it can be underlined that to improve the successful development of the nation, it was necessary to improve the quality of education at all levels of education.

One way that can be done to improve the quality of education is held a sustainable curriculum renewal. The curriculum has a central position in the educational process. In the traditional sense, curriculum is the number of subjects that must be taken by students. The curriculum is also interpreted as an educational program that is planned and executed to achieve the goal of education in schools. In the modern sense, the curriculum is all the learning experiences provided for learners under the responsibility of the school. Thus, the development of students' abilities is determined by the curriculum. If the curriculum has good contents that are relevant to the needs and development of society, it will be able to be a means for educating learners to be qualified human resources to carry out development.

In keeping with the development of science and technology, education curriculum is always developed in Indonesia. Some period of curriculum changes was conducted in 1945, 1968, 1975, 1984,
1986, 1994, 2004, and 2006 known as School-Based Curriculum. School-Based Curriculum (SBC) is an operational curriculum formulated and implemented by each educational unit. SBC is essentially a development of the previous curriculum, namely the curriculum 2004, which was also known as Competency-Based Curriculum.

Generally, there are four characteristics that appear in the implementation of School-Based Curriculum, namely: (1) the granting of broad autonomy to schools; (2) social and parents participations are higher; (3) democratic and professional leadership; and (4) the working team is compact and transparent. In addition, to develop and implement SBC well, then there are seven aspects to be considered, specifically: (1) conducive climate development; (2) the autonomy of schools and educational units; (3) the responsibility of schools and educational units; (4) democratic and professional school leadership; (5) the revitalization of social and parents' participations; (6) an increase in the activities of the teachers working group or subject teachers meeting; and (7) the independence of teachers.

Enactment of School-Based Curriculum is an effort to improve the quality of education according to the needs, conditions, and development of society. The goal is to empower the educational unit to be independence in order to participate actively in the development of the curriculum. Through such participation, it is not only increasing the quality of education, but also increasing the awareness of all the components of school resources, both internally and externally, towards education management in school. The the study results of Bolstad (2004) indicated that the School Based Curriculum was seen as a solution to many of the problems of school education. Centralised curriculum was too slow to keep pace with changing social and educational environments. Through School 
Based Curriculum, schools can improve the quality of education flexibly based on the school conditions.

Based on the Government Regulation Number 19 Year 2005 on National Education Standards, School-Based Curriculum is developed by the school along with the school committee based on the guidelines prepared by the National Education Standards Agency (BSNP). The policy brings enormous benefits, but on the other hand, it also brings higher demands for the schools. Schools have the authority to develop a curriculum in accordance with the needs and conditions of the school. Gopinathan and Deng (2006) revealed that by School-Based Curriculum, schools have more autonomy in designing, planning, and creating educational experiences trough selecting and adapting curriculum materials in the light of their particular situations and needs. Consequently, schools must also have qualified human resources. In order to develop a good curriculum, it is required qualified human resources, both internally and externally.

Implementation of school based curriculum is one of school reform strategies by using bottom-up approach. There are two basic models of school reform strategy, namely top-down and bottom-up. In the topdown approach, school and teachers are considered as implementers of new behaviours developed by policy makers, whereas the bottom-up approach relies heavily on the capasity of schools and teacher communities to turn themselves into innovative learning environments, so that it may result in a better fit of teachers'need, professsional development activities, and ownership, and hence more sustainable changes in classroom practices (Pietarinen, et al., 2017). However, it need to be supported by adequate resources.

This study was aimed at revealing how the arrangement, implementation, and success of SBC implementation, especially in the area of East Java, Indonesia, as the realization of Government Regulation No. 19 of 2005 on the implementation of the National Education Standards. Besides that, the main aim of this study is find out influenceof the implementation of School-Based Curriculum on learning process and students' achievement.

\section{METHODS}

The main objective of this study was to describe the implementation of the School-Based Curriculum, especially at the elementary education level in East Java, Indonesia. It includes the process of curriculum development, curriculum implementation, barrier factors, supporting and troubleshooting steps in the implementation of the curriculum, the successful implementation of the curriculum, and the impact of the implementation of SBC towards learning process and students' achievement.

According to the research objectives, the main research design used in this study was survey. From data collection, data processing, up to conclusion employed survey research design. The approach used in this study was mixing methods. The main frame of this study referred to quantitative completed with qualitative research. Quantitative data were collected and processed by quantitative methods, and qualitative data collected and processed by qualitative methods. Thus, it would result comprehensive findings, and answering the entire research problems carefully.

Research objects of this study were schools in the elementary education level in East Java, which includes elementary school (SD), Junior High School (SMP), Islamic Elementary School (MI), and Islamic Junior High School (MTs). The population that became the main subjects of this study was principals and teachers who were the key actors in the implementation of education in schools. Each educational level was taken to be samples representatively. The sampling technique used in this study was area, cluster, quota, random sampling.

From all regions in East Java, it was taken four regencies/cities as research samples. Each regency/city was captured two districts as the research sample. In accordance with the characteristics of the population, each district was taken 15 to $40 \%$ schools of basic education level as the study sample, which included elementary school (SD), Islamic Elementary School (MI), Junior High Schools (SMP), and Islamic Junior High School (MTs). The principal and three teachers were taken from each school as the research sample. Thus, we get the representative sample.

Based on the results of the sampling, it was selected four areas as research samples, namely Mojokerto City as the sample of north-west region, Malang Regency as the sample from the central region, Blitar Regency as a sample of the southern region, and Pasuruan Regency as the sample of eastern region. Broadly, the number of samples in each city was 47 schools were taken as samples in Malang, 33 schools were taken as samples in Mojokerto, 74 schools were taken as samples in Pasuruan, and 31 schools were taken as samples in Blitar, with principals and teachers as the main data resources.

To obtain research data, this study employed three techniques of collecting data, namely: (1) the questionnaires was used to collect data about the planning, implementation, success, barrier factors, and the positive impact of the implementation of SchoolBased Curriculum to improve the quality of education in schools; (2) interview was used to complete the data obtained through questionnaires, particularly with regard to the process of arranging and implementing School-Based Curriculum; and (3) documentation was used to complete the data obtained through questionnaires, especially the documentative data, such as documents on characteristics of school, characteristics of school resources, and so forth. Research instruments applied in this study was developed based on the object of research. Type of instrument which was developed was the type of rating scale and checklist, included closed and open form.

There were two steps taken to gain good instrument validity. First, it carried out a depth review on the theoretical constructs of studied variables, considered the circumstances exist in the field, as well as developed an outline of content variable based on the study of existing theory carefully. Hence, it would get the research instrument that had the level of content 
validity well. Second, it conducted data collection to instrument trial phase empirically in the field.

Subjects of trial phase were drawn from the research objectives, which were not taken as sample, involved 40 people. The validity of the instruments was examined by analysis of grain-total, and the reliability of the instruments was estimated using Cronbach Alpha analysis. The trial results showed that the research instruments had good validity and reliability with $r$ coefficient $0.77(>0.7)$, so that it could be concluded that the instruments can be employed for data collection well.

In accordance with the research objectives, the study used three techniques of data analysis, particularly: (1) descriptive analysis techniques; (2) Pearson Product Moment Correlation; and (3) analysis of qualitative data. The descriptive analysis technique was performed using descriptive statistics to describe the research data, which was about the arrangement, implementation, success, obstacles, and the positive impact of the implementation of School-Based Curriculum to improve the quality of education at schools.

Some of the descriptive statistics used in this study was mean, standard deviation, frequency distribution and percentage. There were four categories to decribe the data, namely: 3.51 - 4,0 was very good; 2.51 - 3.50 was good; $1.51-2.50$ was fair; and $0-1.50$ was poor. Product Moment Pearson correlation was used to determine the impact of the development and implementation of the curriculum on school achievements, especially students' achievement. Qualitative data analysis technique was used to describe the process of planning and implementation of the School-Based Curriculum at schools.

\section{RESULTS}

The Arrangement and Implementation of SchoolBased Curriculum

Based on the analysis, it can be concluded that most schools at basic level of education in East Java have developed School-Based Curriculum. The main guidelines used as consideration in arranging the curriculum were a guide of the National Education Standards Agency (BSNP), which included the content standard, the graduate competency standard, and the curriculum development guide. The second guideline was the consideration of instruction of the Education Office or the Religious Affairs Office, and the third guideline was the consideration of the school committee, the education foundation, and parents of the students.

The principles that were used to arrange the curriculum were: (1) potential, development and needs of the students, (2) diverse and integrated, (3) responsive to science, technology and arts, (4) relevant to the needs of life, (5) comprehensive and sustainable, (6) for lifelong learning, (7) a balance between national and regional interests. From these two sources of data, the application of these principles was categorized as adequate, with a mean value of 2.65 and 2.59 . In addition, there were twelve operational references that used in arranging the curriculum, namely: (1) increase faith and piety; (2) increase the potential, intelligence, and interest agree with the development; (3) the diversity of potential and characteristics of the region; (4) demands of national and regional development; (5) the demands of the work needs; (6) responsive to the science, technology and the arts; (7) religion; (8) the dynamics of social development; (9) the national unity and national values; (10) the socio-cultural conditions of local society; (11) gender equality; and (12) the characteristics of gender unity.

Components of School-Based Curriculum that were constructed included: (1) the graduate competency standard; (2) the vision and mission of the school; (3) the education objectives; (4) the structure of the curriculum; (5) content of curriculum; (6) the burden of learning; (7) minimum competency criteria; (8) criteria of grade promotion; (9) criteria of graduation; and (10) calendar of education. There were seven steps that need to be carried out by school in arranging the curriculum, namely: (1) analyzing the condition of the school; (2) analyzing the opportunities and challenges; (3) preparing a draft of curriculum; (4) reviewing the draft of curriculum; (5) formulating the final draft of curriculum; (6) conducting improvement and assessment; and (7) disseminating.

Implementation of curriculum could be seen from the Lesson Plan (RPP) and its application in the learning process. Based on the analysis, it could be concluded that the components of Lesson Plan which were developed at schools have met the completeness of the components. If it was viewed from its implementation in the learning process showed the good results. Implementation in the learning process could be observed from the use of learning models, instructional method, the improving of student learning activeness, the use of learning resources, the use of instructional media, and the application of learning evaluation techniques.

On average, teachers used innovative learning model. Type of learning model used in the learning process were active, creative, effective, and enjoyfull learning model, cooperative learning model, contextual teaching-learning model and problem-based learning model. Reviewed from the students' activeness in the learning process were also quite high. The learning resources that were used in the learning process quite varied. Based on the analysis, it could be concluded that teachers quite often used various learning resources in the learning process. The types of learning resources included textbooks, internet materials, books, curriculum, and environment.

The teachers also used various instructional media. The teachers quite often used various instructional media. The types of instructional media used by the teachers were visual media, audio media, audio-visual media, and concrete objects. In term of teaching methods, it could be concluded that most teachers applied a various of teaching methods. The average teacher quite often applied various of teaching methods in the learning process. The types of teaching methods applied in the learning process included lectures, question and answer, discussion, inquiry, simulation method, demonstration, role playing, and 
problem solving. Most teachers often applied between 5 - 6 methods in the learning process.

The majority of teachers also used evaluation techniques of process and product. In term of the target, the majority of teachers have also been carrying out a comprehensive evaluation, which included cognitive, affective and psychomotor. In addition, the evaluation techniques also quite varied. Type of evaluation techniques included paper and pencil tests, portfolio assessment, product assessment, project assessment, attitude assessment, and performance assessment.

Based on the results of analysis, it also showed that the majority of schools have organized the subject of local content. Types of local content which were implemented included local languages, computers, English, crafts, music, reading and writing the Qur'an, and electronics. In addition to local content, the one component that need to be maintained in the implementation of SBC was self development. The types of self development activities which were undertaken included counseling services, extracurricular activities, developing creativity, career guidance, improving life skills, and practice of religion. Besides local content and self-development, one of the main activity that characterized the implementation of SBC was thematic learning for the elementary classes, particularly firts, second, and third grades of elementary school. Based on the analysis, $77.7 \%$ has conducted thematic learning.

The Influence of the Implementation of SchoolBased Curriculum on the Students' Learning Process and Achievement

The Influence of school-based curriculum on the quality of education can be seen from the correlation between components of school-based curriculum and indicators quality of education, namely the teaching quality of teachers, students' learning process and outcome, and school performance. The correlation among the variables was presented in Table 1.

Table 1

Correlation between Coefficients of SBC components and Education Quality Indicators

\begin{tabular}{|c|c|c|c|}
\hline Independent Variables & Dependent Variables & $\mathbf{r}$ & $\mathbf{p}$ \\
\hline \multirow[t]{3}{*}{ Multi-Model of Teaching } & Students' Competence & $0.209 *$ & 0.013 \\
\hline & Quality of Teaching & $0.237 *$ & 0.005 \\
\hline & Students' Activity & $0.228^{*}$ & 0.006 \\
\hline \multirow[t]{2}{*}{ Multi-Resource of Learning } & Schools' Achievement & $0.262^{*}$ & 0.002 \\
\hline & Students' Activity & $0.630 *$ & 0.000 \\
\hline Multi-Media of Instruction & Students' Activity & $0.230^{*}$ & 0.006 \\
\hline \multirow{4}{*}{ Multi-Method of Instruction } & Students' Competence & $0.185^{*}$ & 0.027 \\
\hline & Quality of Teaching & $0.191 *$ & 0.023 \\
\hline & Schools' Achievement & $0.318^{*}$ & 0.000 \\
\hline & Students' Activity & $0.249 *$ & 0.003 \\
\hline \multirow[t]{3}{*}{ Multi-Technique of Evaluation } & Students' Competence & $0.182 *$ & 0.030 \\
\hline & Schools' Achievement & $0.293 *$ & 0.000 \\
\hline & Students' Activity & $0.310^{*}$ & 0.000 \\
\hline \multirow[t]{3}{*}{ Local Content Subjects } & Students' Achievement & $0.172 *$ & 0.040 \\
\hline & Schools' Achievement & $0.225 *$ & 0.007 \\
\hline & Total Achievement & $0.257 *$ & 0.002 \\
\hline \multirow[t]{2}{*}{ Self-Development Subjects } & Students' Non-Academic Achievement & $0.202 *$ & 0.016 \\
\hline & Total Achievement & $0.229^{*}$ & 0.006 \\
\hline
\end{tabular}

Table 2

Correlation among the Arrangement, Implementation, and Results of the Implementation of School-Based Curriculum

\begin{tabular}{|c|c|l|c|c|c|}
\hline \multirow{2}{*}{ No } & \multicolumn{2}{|c|}{ Independent Variables } & \multicolumn{3}{|c|}{ Dependent Variables } \\
\cline { 3 - 6 } & \multicolumn{2}{|c|}{ Y1 } & \multicolumn{2}{|c|}{ Y2 } & \multicolumn{2}{|c|}{ Y3 } \\
\hline 1 & $\mathrm{X} 1$ & Quality of curriculum arrangement process & $0.277^{*}$ & $0.217^{*}$ & 0.128 \\
\hline 2 & $\mathrm{X} 2$ & Ability of schools' resources & $0.317^{*}$ & $0.235^{*}$ & $0.304^{*}$ \\
\hline 3 & $\mathrm{X} 3$ & Support for internal and external components of school & $0.246^{*}$ & 0.126 & 0.135 \\
\hline 4 & $\mathrm{X} 4$ & Quality of curriculum implementation & $0.731^{*}$ & $0.301^{*}$ & 0.123 \\
\hline 5 & $\mathrm{X} 5$ & Percentage of curriculum implementation & $0.428^{*}$ & $0.277^{*}$ & 0.087 \\
\hline
\end{tabular}

Description:

$\mathrm{Y} 1=$ Success of curriculum implementation

Y2 = Achievement of minimum competency standard specified by Schools

Y3 = grade point average of students

$=$ there was a significant influence in the level of significance 0.05

Based on Table 1, it can be concluded that there was effect of the implementation of school-based curriculum components on the increasing of students' activity, teachers' teaching quality, students' achievement, students' competence, and schools' achievement. There was significant correlation between implementation of the local content and self- development subjects and the total achievement, so that it had dominant impact. In addition, there was a significant correlation between affective domain assessment and the grade point average of students. It meant that the affective assessment had a strong impact on the students' grade. 
To obtain accurate results, it was conducted an analysis of correlation between the implementation of SBC and the real accomplishments that were achieved by students comprehensively. Components which were reviewed included the process of arrangement, implementation activities, and the level of success implementating SBC. The process of drafting was examined in terms of the quality of the arrangement process, the ability of school resources, as well as internal and external support for the schools. The activities of implementation was reviewed from the level of implementation of the SBC and the percentage of implementation, and the success of SBC was viewed from the percentage of success, achievement of minimum competence standard, and its impact on the schools' achievement, either students' achievement, teachers' teaching quality, or the average value that was achieved by students. The result summary of the analysis, generally, was presented in Table 2.

\section{DISCUSSION}

Based on the results of data analysis, it could be concluded that the quality of the curriculum arrangement process affected the quality of curriculum implementation. From the three components of the process of drafting, quality of curriculum arrangement process, the ability of schools resources, and the support for internal and external components of the school had a significant positive correlation with the quality of curriculum implementation, and the percentage of curriculum implementation.

When it was associated with the success of implementation, from the three components of the arrangement process also affected the success of curriculum implementation. There was a significant positive correlation between the quality of arrangement process, the ability of schools resources, as well as the support for internal and external components of the school with the success of curriculum implementation and achievement of minimum competency standard specified by schools. However, from three components, only one component which was the ability of schools resources, which had a significant positive correlation with the average of value achieved by students.

There were several obstacles encountered by the schools in implementing SBC, namely lack of funding, limitation of infrastructure, the limited ability and willingness of human resources, limited time, the lack of support of parents and the society, and the obstacles in implementing something new. Effectiveness in the changes of implementing new curriculum was still need time. Although it was different kind of curriculum, the finding was in line with the study of Westbury (2016) that showed schools need time to implement the new curriculum through the systematic steps.

When it was explored further, the quality of curriculum implementation also affected the success of curriculum implementation. Implementation of two components, namely quality of curriculum implementation, and presentage of implementation, both of them had a positive correlation with the percentage of curriculum implementation success rate and the achievement of minimum competency standard specified by schools. When it was seen further, from these two components, none of them which have a positive correlation with the average value achieved by students. However, on the percentage of success of curriculum implementation components and the achievement of minimum competency standard had a significant positive correlation with the average value achieved by students.

Based on these results, it could be concluded that from the side of planning or arrangement, the most powerful component of its support to the value achieved by students was the ability of school resources. Higher resources of the schools, both human resources and material resources, will not only support the arrangement or implementation of the curriculum, but also directly support the final success of the curriculum implementation, namely the increase of students' achievement. The research results was consistent with the study result of Cheung and Wong (2011) that indicated educational changes and innovations with the agreement and support of school heads and teachers tend to have a greater chance of succeeding.

The good quality of curriculum implementation, was also not automatically able to improve students' achievement. The most influencing thing was that the success of curriculum implementation. The more success in implementing the curriculum, the higher the value achieved by students. When it was examined from its characteristics, the School-Based Curriculum more emphasized on students' learning activeness. The higher the student learning activeness, the higher the learning outcomes achieved by students. The finding of the study was consistent with the study results of Akinoglu and Tardogan (2007) that revealed the implementation of problem based active learning model had positively affected students' academic achievement and their attitudes towards the science course.

Basically, the process of student learning occured in a process of interaction between teachers and students, or between students and students. When it was examined from the theory of learning, the learning process in individuals was going through a process of interaction between the individual and his environment. The process of learning only occurs through the interaction of the learner and esence of learning was a change in behavior, either in the cognitive, affective or psychomotor subjects learner. The finding of the research supported the study result of Parveen and Batool (2012) that showed cooperative learning method is superior to traditional method in general science achievement of $9^{\text {th }}$ grade students.

SBC emphasized on efforts to enhance the students learning activeness. The increase of students learning activeness was done using a variety of learning methods, either lectures, question and answer, group discussion, class discussions, individual assignments and so forth, supported by the various learning resources. Through various methods, 
strategies and learning resources, it could be created a wide variety of learning activities. By the wide range of learning activities, it could improve students' learning activeness. Through the students' learning activeness, it would directly improve students' learning outcomes. Meaningful student learning outcomes could only be achieved through meaningful learning experiences. This is consistent with the study results Gordon (2009) that revealed constructivist teaching practices demonstrated significant success in promoting student learning. In addition, the finding of McCaw (2016) showed students identified the importance of learning outside, in the open and through direct experience. Students valued the ongoing practice of personal reflection and inquiry Thus, it could be concluded that the implementation of Scool-based curriculum did not only improve students' learning activeness, but ultimately also improve students' learning outcomes comprehensively.

The research results supported the finding of the Ekeyi (2013) that revealed that demonstration method had significant effect on students achievement than taught with the conventional lecture method. The research results also supported the study of Satya prakasha and Sudhanshu (2014) that showed multimedia teaching significantly promoted achievement with respect to knowledge, understanding, application, and total achievement in biology in comparison to conventional method. In addition, the research results supported the finding of Khan and Shah (2015) that indicated multimedia aided teaching was more effective than traditional one. Students' attitude towards science improved more if multi-media aided teaching method was used as compared to traditional method of teaching. Based on the research their study, Lumadi and Assan (2013) recommended that teachers' training institutions should fully appreciate the needs for training of teachers and be recognizant with the various challenges encountered.

The School-Based Curriculum also emphasized evaluation techniques of process and product. The teachers have also been carrying out a comprehensive evaluation, which included cognitive, affective and psychomotor. By the comprehensive and continous evaluation would increase the students'achievement. The research results supported the study result of Angadi and Akki (2007) that found continous and comprehensive evaluation and fixed interval schedule reinforcement had significant relationship with learning and academic achievements in the subject of english at secondary school level. The research findings also supported the study results of Othman et al. (2013) that showed teachers had readiness to implement school based assessment in the curriculum. The research results also supported the study results of Mansor et al (2013) that found teachers had very positive perspective towards school based assessment. In line with the finding, the study results of Barley (2013) showed that schools had implemented procedure and regulator and provided teachers with adequate support for the effective implementation of achool based assessment. On the other side, Yeung
(2010) showed the school evaluation policy became one effective tool to support the curriculum reform.

The findings of the research also supported to the study results of Pietarinen et al (2017) that showed the top-down-bottom up implementation strategy contributed significantly to the estimated educational impact of curriculum process among the stakeholders. In addition, the findings of the research was in line with the study results of Seehamat et al (2013) that showed the teacher was the main factor in school curriculum development. The findings of the research was also in line with the findings of Shawer research (2017) that indicated preservice teacher training, teaching experience, and teacher content and teaching styles were significant motives behind classroom-level curriculum developments.

\section{CONCLUSION}

Based on the analysis, it could be concluded that most schools have set and implemented SchoolBased Curriculum. The process of curriculum arrangement, average incuded the category of adequate, referred to the correct principles. The ability of human resources and material resources of the schools in arranging curriculum, average was categorized as adequate. Support of internal resources of the school, the society, and the government also included to the category of adequate. The involvement of internal and external of schools personnel were still not fully, whom more to get involve were only the teachers and principals. The components of the curriculum completeness which has developed, average included to the category of quite complete.

Reviewed from its implementation, the schools average to implement the School-Based Curriculum was quite high. The teachers, average was quite often to arrange the lesson plans. The learning models used were quite varied. Types of learning resources used were also quite varied. Learning methods and instructional media were used also quite varied. Learning evaluation techniques were used also quite varied, and included an evaluation of the process and product. Most schools, also have organized local content subjects and conducting self-development. The success of SBC implementation influenced the improvement of the quality of teachers' learning process, students' achievement, students' competence, and schools' achievement. There was a significant positive correlation between the success of curriculum implementation with an average of students' value which achieved the schools.

Based on the conclusions of this study, it could provide some suggestions. The success of curriculum implementation was still not optimal, while from the results of the data analysis, the success of SBC implementation influenced the improvement of students' achievement. Therefore, in order to improve students' achievement, the quality of curriculum implementation needs to be improved. The government, particularly the Ministry of Education and Culture, or the Ministry of Religious Affairs, needs to take appropriate policy that was to improve better implementation of SBC, and provide higher support to 
the schools, seen from the side of funds, infrastructure or human resources for the implementation of SBC. Improving the ability of human resources is the main step to increase the success of the SBC.

\section{REFERENCES}

[1] Akinoglu, O., \& Tardogan, R. O. 2007. The Effects of Problem-Based Active Learning in Science Education on Students' Academic Achievement. Eurasia Journal of Mathematics, Science, \& Technology Education, 3(1), 71-81.

[2] Angadi, G. R., \& Akki, M. B. 2013. Impact of Continuous and Comprehensive Evaluation (CCE) and Fixed Interval Schedule Reinforcement on Academic Achievement of Secondary School Students in English. International Journal of Teacher Educational Research (IJTR), 2(10), 6-17.

[3] Barley, S. Y. M. A. K. 2013. Perspectives of SchoolBased Assessment in the NSS Curriculum Through the Eyes of the Administrative and Teaching Stakeholders in Hong Kong. Hong Kong Teachers' Center Journal, 12, 21-47.

[4] Bolstad, R. 2004. School-Based Curriculum Development: Redefining the Term for New Zealand Schools Today and Tomorrow. Conference of the New Zealand Association of Research in Education, 24-26 November.

[5] Cheung, A. C. K., \& Wong, P. M. 2011. Effect of School Heads' and Teachers' Agreement with the Curriculum Reform on Curriculum Development Progress and Student Learning in Hong Kong. International Journal of Educational Management, 25(5), 453-473.

[6] Diem, C.D., Yusfardiyah, Y., Koniaturrohmah, B., \& Lismayani, L. 2016. Implementation of School-Based Curriculum as Perceived by Secondary School Teachers of English. Indonesia Journal of Applied Linguistics, 5(2), 167-175.

[7] Ekeyi, D. N. 2013. Effect of Demonstration Method of Teaching on Students' Achievement in Agricultural Science. World Journal of Education, 3(6), 1-7.

[8] Gopinathan, S., \& Deng, Z. 2006. Fostering SchoolBased Curriculum Development in the Contex of New Educational Initiatives in SINGAPORE. Planning and Chaning, 37(1), 93-110.

[9] Gordon, M. 2009. The Misuses and Effective Uses of Constructivist Teaching. Teachers and Teaching, 15(6), 737-746.

[10] Khan, M., \& Shah, I. 2015. Impact of MultimediaAided Teaching on Students' Academic Achievement and Attitude at Elementary Level. US-China Education Review, 5(5), 349-360.

[11] Lumadi, M. W., \& Assan, T. E. B. 2013. School-Based Curriculum Development: Experiences from the NorthWest Schools. Int J Edu Sci, 5(3), 237-244.

[12] Mansor, A.N., Leng, O.H., Rasul, M.S., Raof , R.A., \& Yusoff, N. 2013. The Benefits of School Based Assessment. Asian Social Science, 9(8), 101-106.

[13] McCaw, C. (2016). Secondary school students' ideas of learning and schooling. A case-study of an intensive, experiential middle-years program. Curriculum Perspectives, 36(2), 1-13.

[14] Othman, T., Salleh, N.M., \& Norani, N.A.M. 2013. The Implementation of School Based Assessment in Primary School Standard Curriculum. International Journal of Education and Research, 1(7), 1-10.

[15] Parveen, Q., \& Batool, S. 2012. Effect of Cooperative Learning on Achievement of Students in General
Science at Secondary Level. International Education Studies, 2, 154-158.

[16] Pietarinen, J., Pyhalto, K., \& Soini, T. 2017. LargeScale Curriculum Reform in Finland-Exploring the Interrelation between Implementation Strategy, the Function of the Reform, and Curriculum Coherence. The Curriculum Journal, 28(1), 22-40.

[17] Satyaprakasha, C.V., \& Sudhanshu, Y. 2014. Effect of Multimedia Teaching on Achievement in Biology. International Journal of Education and Psychological Research (IJEPR), 3(1), 41-45.

[18] Seehamat, L., Sarnrattana, U., Tungkasamit, A., \& Srisawasdi, N. 2014. Need Assessment for Curriculum Development about Water Resources Management: A Case Study of Nam Phong Basin. Procedia-Social and Behavioral Sciences, 116, 1763-1765.

[19] Shawer, S. F. 2017. Teacher-Driven Curriculum Development at the Classroom Level: Implications for Curriculum, Pedagogy and Teacher Training. Teaching and Teacher Education, 63, 296-313.

[20] Westbury, L. 2016. State-Based Curriculum-Making: The Illinois Learning Standards. Journal of Curriculum Studies, 48(6), 783-802.

[21] Yeung, S. S. 2010. Using School Evaluating Policy to Effect Curriculum Change? A Reflection on the SSE and ESR Exercise in Hong Kong. Educational Research Association, 25(2), 187-210. 